\title{
PASANG SURUT OTONOMI DAERAH DI INDONESIA
}

\author{
Dadang Sufianto \\ Magister Ilmu Pemerintahan \\ Universitas Jenderal Achmad Yani
}

\begin{abstract}
Abstrak
Otonomi daerah di Indonesia telah ada sejak tahun 1903 yang terbagi ke dalam 3 (tiga) masa yakni masa penjajahan Belanda, masa penjajahan Jepang, dan masa Indonesia merdeka. Dalam kurun waktu itu, perubahan situasi politik telah mewarnai perubahan prinsip pemberian otonomi kepada daerah. Dari sejak ada sampai sekarang, otonomi daerah di Indonesia mengalami perubahan mengikuti irama 'tarik-menarik kewenangan Pusat-Daerah.' Otonomi daerah kadang membesar dan kadang mengecil. Itulah pasang surut otonomi daerah yang telah dan mungkin akan terus berlangsung di NKRI.
\end{abstract}

Kata kunci: Otonomi, desentralisasi, pemerintahan, daerah

\begin{abstract}
Regional autonomy in Indonesia has existed since 1903 which is divided into 3 (three) periods, namely the Dutch colonial period, the Japanese colonial period, and the period of Indonesia's independence. During that time, the change of the political situation had colored the change in the principle of granting regional autonomy. Since that time until now, regional autonomy in Indonesia has often changed following the rhythm of 'pulling to each other between Central-Regional authority.' Regional autonomy sometimes enlarges and sometimes shrinks. That is the ups and downs of regional autonomy that have been and will probably continue in the Republic of Indonesia.
\end{abstract}

Keywords: Autonomy, decentralization, governance, regions

\section{PENDAHULUAN}

Praktik penyelenggaraan pemerintahan di negara-negara kesatuan pada umumnya menggunakan asas sentralisasi dan desentralisasi. Di negara-negara yang menggunakan asas sentralisasi ekstrem, semua urusan pemerintahan dijalankan oleh pemerintah pusat, sedangkan pemerintah daerah hanya berperan sebagai pelaksana saja. Sekarang, pelaksanaan asas seperti itu sudah sangat 
jarang digunakan, kecuali di negara-negara yang sangat kecil dengan jumlah penduduk yang sedikit. Pada masa sekarang penggunaan asas sentralisasi telah diperlunak dengan asas dekonsentrasi, yakni pelimpahan wewenang dari pemerintah pusat kepada aparatnya yang ada di daerah. Selain dengan asas itu, digunakan pula asas desentralisasi (teritorial), yakni penyerahan wewenang dari pemerintah pusat kepada daerah sehingga menghadirkan otonomi daerah.

Otonomi daerah di Indonesia telah ada sejak dikeluarkan Decentralisatiewet S 1903/329 oleh Pemerintah Belanda pada tahun 1903. Namun, banyak orang yang tidak mengetahui hal ini. Era otonomi daerah seakanakan baru dimulai tahun 1999 sejak pemerintah RI mengeluarkan UU No. 22 tahun 1999 tentang Pemerintahan Daerah. Selain itu, tidak sedikit pula orang menduga bahwa dengan otonomi daerah segala urusan pemerintahan dapat dikelola oleh daerah.

Itulah latar belakang penyusunan karya tulis ini. Sedangkan rumusan masalahnya adalah sebagai berikut:

1) sejak kapan otonomi daerah ada di Indonesia;

2) bagaimanakah pasang surut otonomi daerah di Indonesia dari sejak ada sampai sekarang.

\section{PEMBAHASAN}

Kata "otonomi" menurut Kamus Besar Bahasa Indonesia (1996:709) berarti pemerintahan sendiri. Sedangkan menurut Cambridge Dictionary of English (1995:82), autonomy is the right of a group people to govern itself or to organize its own activities (otonomi adalah hak sekelompok orang untuk mengurus dirinya sendiri atau hak untuk mengorganisasikan aktivitasaktivitasnya).

Jika arti kata otonomi secara leksikografis (perkamusan) tadi dihubungkan dengan kenegaraan/pemerintahan, maka kedaulatan (sovereignty) menurut sebagian ahli dapat dikatakan otonomi negara. Namun, istilah otonomi negara tidak lazim digunakan. Yang lazim digunakan adalah otonomi desa (otonomi yang dimiliki desa) dan otonomi daerah (otonomi yang dimiliki daerah). 
Apa arti otonomi daerah menurut para akhli dan peraturan perundangundangan?

Dari pidato Wakil Pemerintah untuk Bestuurshervorming (penataan pemerintahan) tgl. 4 Desember 1923 di depan Volksraad (dalam Soejito, 1981:39) diketahui bahwa otonomi daerah adalah sesuatu hal yang diserahkan oleh pemerintahan yang lebih tinggi kepada persekutuan yang lebih rendah untuk diatur seluruhnya secara bebas menjadi urusan rumah-tangganya sendiri. Menurut Bray (dalam Fasli Jalal, 1997:1): “Otonomi Daerah adalah wewenang untuk mengambil segala keputusan yang berhubungan dengan penggunaan berbagai resources yang dimiliki jenjang pemerintahan yang lebih rendah karena pemberian dari jenjang pemerintahan yang lebih tinggi. Sedangkan menurut Sadu Wasistiono (1999:7): “Otonomi daerah pada dasarnya adalah hak suatu kesatuan masyarakat hukum untuk mengatur dan mengurus rumah tangganya sendiri secara bebas. Selain mereka, Koswara (2000:13) mengemukakan bahwa otonomi daerah pada hakekatnya merupakan penerapan konsep "areal division of power" yang membagi kekuasaan suatu negara secara vertikal. Dalam sistem ini, kekuasaan negara akan terbagi antara pemerintah pusat di satu pihak dan pemerintah daerah di lain pihak. Sedangkan menurut kebijakan, dalam pasal 1 UU No. 23 tahun 2014 tentang Pemerintahan Daerah dinyatakan: "Otonomi daerah adalah hak, wewenang, dan kewajiban daerah otonom untuk mengatur dan mengurus sendiri Urusan Pemerintahan dan kepentingan masyarakat setempat dalam sistem Negara Kesatuan Republik Indonesia.

Dari pendapat beberapa akhli dan kebijakan di atas, penulis menyimpulkan bahwa otonomi daerah adalah wewenang yang diserahkan oleh pemerintah pusat kepada daerah otonom untuk mengelola urusan pemerintahan tertentu yang ditetapkan sebagai urusan rumah tangga daerah berdasarkan peraturan perundang-undangan.

Wewenang dalam pengertian otonomi daerah merupakan turunan dari kekuasaan eksekutif dan legislatif pemerintahan negara (tidak ada turunan kekuasaan yudikatif). Wewenang itu diserahkan, berarti diberikan oleh Pusat kepada Daerah, terlepas dari anggapan apakah wewenang tersebut memang 
sepatutnya menjadi hak/kewajiban daerah atau bukan. Wewenang itu diserahkan secara formal, yaitu ditetapkan secara resmi dalam suatu/beberapa peraturan perundang-undangan (UU dan PP). Wewenang tersebut diberikan untuk menyelenggarakan urusan yang dijadikan urusan rumah tangga daerah, bukan wewenang untuk menyelenggarakan urusan pusat yang ada di daerah. Urusanurusan yang ditetapkan sebagai urusan rumahtangga daerah adalah sebagian dari urusan/bidang urusan pemerintahan yang asalnya merupakan urusan pusat.

Otonomi daerah menyangkut 'nasib' kebanyakan orang, terutama yang berada di daerah. Kebijakan mengenai otonomi daerah dan implementasinya diyakini berpengaruh besar terhadap dinamika politik, ekonomi, sosial, budaya dan hankam di tingkat lokal dan nasional. Secara politis, otonomi daerah merupakan wujud demokratisasi dalam penyelenggaraan pemerintahan. Dengan otonomi daerah, masyarakat daerah berpeluang untuk lebih merasakan bahwa pemerintahnya itu berasal dari, untuk dan oleh mereka. Secara ekonomis, otonomi daerah merupakan dorongan untuk memajukan perekonomian daerah sekaligus memperkuat perekonomian nasional. Daerah lebih berpeluang untuk mengembangkan dan memanfaatkan potensi lokalnya. Kondisi yang diharapkan ialah pertumbuhan dan pemerataan ekonomi di daerah-daerah dapat terus meningkat. Secara sosiologis, otonomi daerah dapat memberi peluang penguatan peran sosial komponen daerah yang potensial untuk membangun dirinya secara lebih dinamis. Masalah-masalah sosial yang semakin kompleks, diharapkan dapat diimbangi oleh kemampuan daerah dalam mengatasinya. Secara budaya, otonomi daerah memberi peluang kepada masyarakat daerah untuk mengangkat nilai-nilai kearifan lokal guna memperkuat jati diri bangsa. Harapannya, nilai-nilai asing yang tidak sesuai dengan kepribadian bangsa dapat disaring dan diimbangi. Secara pertahanan, otonomi daerah berpotensi memperkuat ketahanan daerah untuk memperkuat ketahanan nasional agar NKRI terpelihara dan tetap terjaga keutuhannya. 


\section{Riwayat Otonomi Daerah Di Indonesia}

Tidak sedikit orang yang mengira bahwa otonomi daerah baru mulai ada di Indonesia setelah UU No. 22 tahun 2009 tentang Pemerintahan Daerah ditetapkan. Padahal tidak demikian. Otonomi daerah telah ada sejak masa penjajahan Belanda.

Dari beberapa sumber, antara lain hasil penelitian The Liang Gie tahun 1962-1965 tentang desentralisasi dalam bidang pemerintahan, diperoleh pengetahuan mengenai riwayat otonomi daerah di Indonesia berikut besarannya pada masa penjajahan Belanda, masa penjajahan Jepang, dan masa setelah NKRI berdiri sampai sekarang.

\section{A. Masa Penjajahan Belanda}

Pada masa ini, perundang-undangan yang terkait dengan riwayat otonomi daerah di Indonesia (waktu itu, Hindia Belanda) antara lain sebagai berikut:

1. Decentralisatiewet S 1903/329 (ketentuan tentang desentralisasi) yang ditindak-lanjuti dengan Decentralisatiebesluit S 1905/137 (keputusan Gubernur Jendral) tentang desentralisasi dan Locale RadenordonantieS 1905/181 (undang-undang tentang Dewan Lokal). Dengan peraturan perundang-undangan tersebut, di wilayah Hindia Belanda dibentuk daerah-daerah otonom setingkat keresidenan dan kota di Jawa dan Madura. Misalnya pembentukan Gemeente Batavia (S 1905/204).

2. Bestuurshervormingwet S1922/216 (ketentuan tentang penyusunan kembali pemerintahan) yang ditindaklanjuti dengan Provincieordonantie S 1924/78, Regentschapordonantie S 1924/79 dan Stadsgemeenteordonantie S 1924/365 untuk pembentukan pemerintahan setingkat provinsi, kabupaten dan kotaparaja di Jawa dan Madura. Provinsi Jawa Barat misalnya dibentuk pada tahun 1925 dengan S 1925/378. Sedangkan di luar Jawa dan Madura, pembentukan daerah masih berdasarkan S 1903, misalnya pembentukan keresidenan Palembang dan Sumatra Barat serta kotapraja Medan dan Makasar pada tahun 1938. 
Pada masa ini, pemberian otonomi daerah selain didorong oleh gerakan Ethische Politiek (Politik Etik) untuk meningkatkan kecerdasan dan peran politik bangsa pribumi, juga yang terpenting adalah untuk meringankan beban keuangan pemerintah pusat dan untuk mengimbangi gerakan-gerakan kebangsaan dalam rangka mempertahankan kolonialisme di Indonesia. Jenis-jenis urusan berikut wewenang yang diserahkan untuk mengurus rumah tangga daerah pada waktu itu, belum secara rinci disebutkan. Yang diserahkan kepada daerah baru mengenai pengurusan keuangan dan peluang untuk penentuan para pejabat pemerintahan daerah dari kalangan pribumi.

\section{B. Masa Penjajahan Jepang}

Peraturan perundang-undangan yang terkait dengan riwayat otonomi daerah di Indonesia antara lain sebagai berikut:

1. Undang-undang No. 1 tahun 1942 tentang Menjalankan Pemerintahan Balatentara. Menurut undang-undang ini, wilayah bekas jajahan Belanda dibagi menjadi 3 (tiga) daerah pemerintahan yaitu 1) daerah pemerintahan militer Jawa dan Madura yang dijalankan oleh angkatan darat dan berkedudukan di Jakarta, 2) daerah pemerintahan militer Sumatra yang dijalankan oleh angkatan darat dan berkedudukan di Bukittinggi, dan 3) daerah pemerintahan militer Sulawesi, Kalimantan, Nusa Tenggara, Maluku dan Irian Barat yang dijalankan oleh angkatan laut dan berkedudukan di Makasar.

2. Undang-undang No. 27 tahun 1942 tentang Perubahan Tata Pemerintahan Daerah. Menurut undang-undang ini, Jawa dibagi ke dalam beberapa Syuu (keresidenan), Ken (kabupaten) dan Si (kotapraja).

3. Undang-undang No. 28 tahun 1942 tentang pembentukan beberapa keresidenan dan kotapraja luar biasa Jakarta (sebagai tindak lanjut dari no.2 di atas). Jakarta secara khusus dijadikan Tokubetu Si (kotapraja luar biasa setingkat keresidenan) yang diperintah langsung oleh Gunseikan (Pembesar Pemerintah Balatentara Jepang).

4. Osamu Seirei (peraturan yang dikeluarkan Gunseikan) No.12 tahun 1943 tentang pembentukan beberapa Ken (kabupaten) dan Si (kotaparja). 
5. Osamu Seirei No. 37 tahun 1943 tentang pembentukan dewan-dewan perwakilan rakyat di tingkat keresidenan dan di Jakarta.

Pada masa ini, daerah-daerah provinsi ditiadakan. Otonomi daerah pada masa ini hampir sama dengan masa sebelumnya, karena Jepang, sepanjang tidak bertentangan dengan strategi militer dalam mengahadapi perang, masih tetap menggunakan prinsip-prinsip desentralisasi peninggalan Belanda sampai dengan tahun 1945. Daerah didorong untuk dapat memenuhi kebutuhannya sendiri dan mampu memenuhi permintaan Jepang untuk keperluan perang (harta benda dan manusianya).

\section{Masa Negara Kesatuan Republik Indonesia}

Setelah masa penjajahan Jepang berakhir dan NKRI berdiri pada tahun 1945, peraturan perundang-undangan yang terkait dengan riwayat otonomi daerah di Indonesia antara lain sebagai berikut :

1. Undang-undang No.1 tahun 1945 tentang Peraturan Mengenai Kedudukan Komite Nasional Daerah. Undang-undang ini ditetapkan berdasarkan UUD 1945 yang pada intinya mengatur antara lain tentang pembentukan daerah otonom keresidenan, kota dan kabupaten. Pada masa pemberlakuan undang-undang ini, otonomi yang diberikan kepada daerah disebut 'otonomi Indonesia' yang berdasarkan kedaulatan rakyat dan karenanya lebih luas dari otonomi daerah jaman Belanda. Jenis urusan dan wewenang yang dijadikan urusan rumah tangga daerah belum ditetapkan secara rinci. Pembatasannya, apapun dapat diputuskan dan dilakukan daerah sepanjang tidak bertentangan dengan peraturan pusat dan daerah yang lebih tinggi. Untuk membiayai urusan rumah tangga daerah, hampir $100 \%$ ditanggung oleh daerah sesuai dengan kemampuan masing-masing. Pada masa ini, kebijakan otonomi daerah dan implementasinya lebih ditujukan pada upaya mempertahankan kemerdekaan.

2. Undang-undang No. 22 Tahun 1948 Tentang Penetapan Aturan-Aturan Pokok Mengenai Pemerintahan Sendiri Di Daerah-Daerah Yang Berhak Mengatur Dan Mengurus Rumah Tangganya Sendiri. Undang-undang ini ditetapkan berdasarkan UUD 1945. Menurut undang-undang ini, terdapat 
3 (tiga) tingkatan daerah yaitu provinsi, kabupaten/kota besar, dan desa/kota kecil. Selain daerah otonom (biasa) terdapat pula daerah istimewa yang setingkat provinsi dan kabupaten. Pada periode ini dibentuk daerah-daerah sekaligus dengan penyerahan otonominya (urusan pangkal). Prinsip pemberian otonomi kepada daerah tidak diegaskan. Urusan yang diserahkan kepada provinsi untuk dijadikan urusan rumah tangganya pada umumnya meliputi 15 urusan yaitu urusan-urusan 1) umum, 2) pemerintahan umum, 3) agraria, 4) pekerjaan umum (pengairan, jalan, dan gedung), 5) pertanian, perikanan, dan koperasi, 6) kehewanan, 7) kerajinan, perdagangan dalam negeri, dan perindustrian, 8) perburuhan, 9) sosial, 10) distribusi, 11) penerangan, 12) pendidikan, pengajaran, dan kebudayaan, 13) kesehatan, 14) perusahaan, dan 15) urusan lalu lintas dan angkutan bermotor. Sedangkan kepada daerah-daerah kabupaten yang sudah terbentuk diserahkan 14 urusan (hampir sama dengan urusan provinsi kecuali urusan lalu lintas dan angkutan bermotor). Walaupun isi undang-undang ini dirasakan lebih lengkap dari UU No.1 tahun 1945, dalam praktiknya tidak sempat dilaksanakan sepenuhnya karena kesibukan menghadapi pemberontakan Madiun dan agresi Belanda ke berbagai daerah. Pelaksanaan undang-undang ini sempat terkendala pula oleh pembentukan RIS (Republik Indonesia Serikat) yang salah satu negara bagiannya adalah NKRI. Setelah NKRI utuh kembali, dari sejumlah urusan-urusan tadi, hanya setengahnya yang dapat diserahkan kepada daerah dengan peraturan-peraturan khusus.

3. Undang-undang No. 1 tahun 1957 Tentang Pokok-Pokok Pemerintahan Daerah. Undang-undang ini ditetapkan berdasarkan UUDS 1950. Menurut undang-undang ini, daerah dibedakan dalam 3 tingkat yakni daerah swatantra/istimewa tingkat I setingkat provinsi membawahi seluruh daerah/istimewa swatantra tingkat II setingkat kabupaten dan kotapraja (kota besar/kecil). Daerah swatantra tingkat II kabupaten membawahi daerah tingkat III (jika diperlukan) yang namanya ditentukan dalam masing-masing peraturan pembentukannya, sedangkan Kotapraja daerah 
tingkat II tidak membawahi daerah tingkat III. Khusus Kotapraja Jakarta Raya berada dalam posisi setingkat provinsi (daerah tingkat I). Dalam hal otonomi daerah, undang-undang ini menganut sistem otonomi riil. Urusan-urusan pusat dan urusan rumah-tangga daerah tidak ditetapkan secara rinci, tetapi disesuaikan dengan kebutuhan dan kemampuan riil pusat/daerah berdasarkan keadaan dan faktor-faktor nyata.

4. Undang-undang No. 18 tahun 1965 tentang Pokok-Pokok Pemerintah Daerah. Undang-undang ini merupakan tindak lanjut dari Dekrit Presiden 1959 (kembali ke UUD 1945). Menurut undang-undang ini, seluruh wilayah RI dibagi habis ke dalam daerah-daerah otonom yang tersusun dalam 3 tingkatan yaitu provinsi / kotaraya sebagai DT I, kabupaten / kodya sebagai DT II dan kecamatan sebagai DT III. Mengenai otonomi daerah, undang-undang ini juga menganut sistem seperti UU no. 1 tahun 1957 yaitu sistem otonomi riil namun memberi peluang untuk menyerahkan sebagian urusan pusat yang diatur dengan Peraturan Pemerintah.

5. Undang-undang No. 5 tahun 1974 tentang Pokok-Pokok Pemerintahan Di Daerah. Undang-undang ini ditetapkan berdasarkan UUD 1945 dan merupakan tindak lanjut dari adanya penggantian Presiden RI dari Bung Karno (Orla) kepada Pak Harto (Orba). Dengan undang-undang ini dibentuk Daerah (daerah otonom, dalam rangka desentralisasi) dan Wilayah (daerah administrasi, dalam rangka dekonsentrasi). Daerah tersusun dalam 2 tingkat, yaitu Daerah Tingkat (DT) I dan Daerah Tingkat II, sedangkan Wilayah tersusun ke dalam 5 tingkat yaitu Provinsi, Kabupaten/Kodya, Kotip (bagi yang ada), Kecamatan, dan Kelurahan. Mengenai otonomi daerah, undang-undang ini menganut sistem otonomi yang nyata dan bertanggungjawab dengan titik beratnya diletakkan pada DT II sebagaimana ditegaskan dalam PP No. 45 tahun 1992 tentang Penyelenggaraan Otonomi Daerah Dengan Titik Berat Pada Daerah Tingkat II.Pada masa ini, urusan yang dijadikan urusan rumah tangga daerah, selain urusan pangkal yang telah diterima daerah pada saat 
pembentukannya, diserahkan pula urusan-urusan tambahan yang ditetapkan dalam berbagai peraturan. Walaupun demikian, dalam praktiknya wewenang DT II sangat terbatas. Contoh, pembentukan kecamatan masih merupakan wewenang Pusat, pendirian SLTP dan SLTA negeri masih wewenang provinsi, dan pembentukan desa masih wewenang Gubernur.

6. Undang-undang No.22 tahun 1999 tentang Pemerintahan Daerah. Undang-undang ini ditetapkan berdasarkan UUD 1945 (sebelum amandemen), sebagai tindak lanjut dari Tap MPR RI No. XV/MPR/1998 tentang Penyelenggaraan Otonomi Daerah, Pembagian dan Pemanfaatan Sumber Daya Nasional yang Berkeadilan serta Perimbangan Keuangan Pusat dan Daerah dalam Kerangka Negara Kesatuan Republik Indonesia. Undang-undang ini menganut prinsip pemberian otonomi yang seluasluasnya, nyata, dan bertanggung jawab. Dengan undang-undang ini, ditetapkan Daerah Provinsi dan Daerah Kabupaten/Kota yang masingmasing bersifat otonom (asas desentralisasi). Provinsi tidak membawahi Kabupaten/Kota. Penyebutan Provinsi DT I diubah dengan Provinsi, dan penyebutan Kabupaten/Kotamadya DT II diubah dengan Kabupaten/Kota. Pada masa pemberlakuan undang-undang ini, dikeluarkan Peraturan Pemerintah (PP) No. 25 tahun 2000 tentang Kewenangan Pemerintah dan Kewenangan Provinsi Sebagai Daerah Otonom. Kewenangan pemerintah (pusat) meliputi bidang-bidang 1) politik luar negeri, 2) hankam, 3) peradilan, 4) moneter / fiskal nasional, 5) agama, dan 6) kewenangan lain. Yang dimaksud kewenangan lain di sini yaitu kewenangan dalam urusan-urusan pertanian (8), kelautan (5), pertambangan dan energi (11), kehutanan dan perkebunan (16), perindustrian dan perdagangan (10), perkoperasian (4), penanaman modal (1), kepariwisataan (3), ketenagakerjaan (3), kesehatan (11), dikbud (10), sosial (6), penataan ruang (4), pertanahan (5), permukiman (4), pekerjaan umum (5), perhubungan (31), lingkungan hidup (5), politik dalam negeri dan administrasi publik (19), pengembangan otda (21), perimbangan 
keuangan (2), kependudukan (5), olah raga (3), hukum dan perundangundangan (6 kewenangan) dan bidang lain (16). Sedangkan kewenangan provinsi sebagai daerah otonom terdiri dari kewenangan-kewenangan: 1) yang bersifat lintas kabupaten/kota, 2) yang belum mampu dilaksanakan kabupaten/kota, 3) yang disepakati dengan kabupaten/kota, dan 4) kewenangan tertentu. Yang dimaksud kewenangan tertentu di sini yaitu kewenangan dalam bidang pertanian (16), kelautan (5), pertambangan dan energi (5), hutbun (18), perindag (3), koperasi (1), penanaman modal (1), ketenagakerjaan (2), kesehatan (5), dikbud (6), sosial (3), penataan ruang (2), permukiman (1), pekerjaan umum (8), perhubungan (13), lingkungan hidup (6), poldagri dan administrasi publik (9), pengembangan otda (1), perimbangan keuangan (2),hukum dan perundang-undangan (1) Kewenangan kabupaten terdiri dari 11 bidang kewenangan wajib yaitu : 1) pekerjaan umum, 2) kesehatan, 3) pendidikan dan kebudayaan, 4) pertanian, 5) perhubungan, 6) industri dan perdagangan, 7) penanaman modal, 8) lingkungan hidup, 9) pertanahan, 10) koperasi, dan 11) tenaga kerja. Selain 11 kewenangan wajib tersebut, dapat pula ditambahkan kewenangan lain yang bukan kewenangan Pemerintah Pusat dan Provinsi Sebagai Daerah Otonom. Kewenangan kota, selain sama dengan kewenangan kabupaten, ditambah pula dengan kewenangan yang sesuai dengan kebutuhan khas perkotaan seperti pemadam kebakaran, kebersihan, pertamanan dan tata kota.Karena kewenangan kabupaten/kota itu demikian sangat luas, maka sebelum dijalankan, kewenangannya itu perlu diinventarisasi terlebih dahulu oleh masing-masing kabupaten / kota dan dimintakan pengakuannya terlebih dahulu dari Pemerintah Pusat sebagaimana diatur dalam Keppres No. 5 tahun 2001 tentang Pelaksanaan Pengakuan Kewenangan Kabupaten/Kota. Sekedar contoh, berdasarkan inventarisasi pada tahun 2002, kabupaten Cianjur memiliki 1405 kewenangan untuk menjalankan 20 bidang urusan yang dijadikan urusan rumah tangga daerah dan telah mendapat pengakuan dari Pusat melalui 
Kepmendagri No. 130-67 tahun 2002 tentang Pengakuan Kewenangan Kabupaten/Kota.

7. Undang-undang No. 32 tahun 2004 tentang Pemerintahan Daerah. Undang-undang ini dikeluarkan berdasarkan UUD 1945 yang telah diamandemen. Dengan undang-undang ini, NKRI dibagi atas daerah provinsi dan provinsi dibagi atas kabupaten/kota. Pemberian otonomi daerah dianut prinsip otonomi yang seluas-luasnya, nyata, dan bertanggung jawab. Yang dimaksud dengan otonomi yang seluasluasnya ialah bahwa daerah diberi wewenang untuk mengelola semua urusan pemerintahan kecuali urusan yang tetap dipegang Pusat. Dalam ayat (3) pasal 10 UU No. 32/2004, urusan yang wewenang sepenuhnya dipegang Pusat adalah 1) politik luar negeri, 2) pertahanan, 3) keamanan, 4) yustisi, 5) fiskal/moneter nasional dan 6) agama. Otonomi yang nyata ialah bahwa daerah diberi tugas, wewenang dan kewajiban yang senyatanya telah ada dan berpotensi untuk tumbuh, hidup dan berkembang sesuai dengan potensi dan kekhasan daerah. Implikasinya, isi dan jenis otda setiap daerah dapat tidak sama. Karena itu, selain urusan wajib, kepada Daerah tertentu diberikan pula wewenang pengelolaan urusan pilihan. Urusan wajib adalah urusan yang sangat mendasar yang berkaitan dengan hak dan pelayanan dasar warga negara, sedangkan urusan pilihan adalah urusan yang secara nyata ada di Daerah dan berpotensi untuk meningkatkan kesejahteraan masyarakat sesuai dengan kondisi, kekhasan dan potensi unggulan daerah. Otonomi yang bertanggungjawab ialah bahwa daerah dalam menjalankan otda-nya harus benar-benar sejalan dengan tujuan pemberian otonomi daerah yaitu memberdayakan daerah termasuk meningkatkan kesejahteraan masyarakat sebagai bagian utama tujuan nasional. Dengan undang-undang ini, otonomi daerah provinsi lebih jelas dan lebih luas, berbeda sekali dengan kondisi pada waktu pemberlakuan UU no. 22 tahun 1999 yang kewenangannya terbatas. Dengan undang-undang yang berlaku sekarang, yang membedakan otonomi daerah provinsi dengan kabupaten/kota adalah dalam hal 
skalanya. Sebagai tindak lanjut dari undang-undang ini, pemerintah mengeluarkan PP no. 38 tahun 2007 tentang Pembagian Urusan Pemerintahan Antara Pemerintah, Pemerintah Daerah Provinsi, Dan Pemerintah Kabupaten/Kota. Salah satu contoh praktiknya dalam bidang pendidikan, walaupun urusan pendidikan dasar merupakan urusan wajib kabupaten/kota, namun urusan kurikulumnya (nasional) tetap ditangani pusat, sedangkan operasionalisasinya diserahkan kepada daerah (kabupaten/kota); pengaturan hari efektif belajar masih ditangani pusat, tetapi kalender pendidikannya diserahkan kepada daerah; tenaga kependidikan organik (PNS) direkrut Pusat, sedangkan penempatannya diserahkan kepada daerah. Urusan-urusan tersebut pada dasarnya merupakan kelompok-kelompok pekerjaan untuk menjalankan fungsifungsi pemerintah yaitu pengaturan, pembangunan, dan pelayanan umum.

8. UU No. 23 tahun 2014 tentang Pemerintahan Daerah. Dengan undangundang ini, Negara Kesatuan Republik Indonesia dibagi atas Daerah provinsi dan Daerah provinsi itu dibagi atas Daerah kabupaten dan kota, sedangkan Daerah kabupaten/kota dibagi atas Kecamatan dan Kecamatan dibagi atas kelurahan dan/atau Desa. Prinsip pemberian otonomi daerah adalah otonomi yang seluas-seluasnya berdasarkan prinsip negara kesatuan. Dalam negara kesatuan kedaulatan hanya ada pada pemerintahan negara atau pemerintahan nasional dan tidak ada kedaulatan pada Daerah. Oleh karena itu, seluas apapun otonomi yang diberikan kepada Daerah, tanggung jawab akhir penyelenggaraan Pemerintahan Daerah akan tetap berada di tangan Pemerintah Pusat. Untuk itu Pemerintahan Daerah pada negara kesatuan merupakan satu kesatuan dengan Pemerintahan Nasional. Sejalan dengan itu, kebijakan yang dibuat dan dilaksanakan oleh Daerah merupakan bagian integral dari kebijakan nasional. Di dalam undangundang ini disebutkan adanya 3 (tiga) golongan urusan pemerintahan yaitu 1) urusan pemerintahan absolut (yang sepenuhnya menjadi kewenangan Pemerintah Pusat, yaitu politik luar negeri, pertahanan, keamanan, yustisi, moneter dan fiskal nasional, dan agama); 2) urusan pemerintahan 
konkuren (yang dibagi antara Pemerintah Pusat dan Daerah provinsi dan Daerah kabupaten/kota); dan 3) urusan pemerintahan umum (yang menjadi kewenangan Presiden sebagai kepala pemerintahan). Urusan pemerintahan yang diserahkan kepada daerah adalah 24 urusan konkuren wajib (pendidikan; kesehatan; pekerjaan umum dan penataan ruang; perumahan rakyat dan kawasan permukiman; ketenteraman, ketertiban umum, dan pelindungan masyarakat; sosial, tenaga kerja; pemberdayaan perempuan dan pelindungan anak; pangan; pertanahan; lingkungan hidup; administrasi kependudukan dan pencatatan sipil; pemberdayaan masyarakat dan Desa; pengendalian penduduk dan keluarga berencana; perhubungan; komunikasi dan informatika; koperasi, usaha kecil, dan menengah; penanaman modal; kepemudaan dan olah raga; statistik; persandian; kebudayaan; perpustakaan; dan kearsipan) dan 8 urusan konkuren pilihan (kelautan dan perikanan; pariwisata; pertanian; kehutanan; energi dan sumber daya mineral; perdagangan; perindustrian; dan transmigrasi). Urusan pemerintahan umum di Daerah pelaksanaannya dilimpahkan oleh Presiden kepada Gubernur sebagai Kepala Pemerintahan Provinsi dan kepada Bupati/Walikota sebagai Kepala Pemerintahan Kabupaten/Kota, yaitu a) pembinaan wawasan kebangsaan dan ketahanan nasional dalam rangka memantapkan pengamalan Pancasila, pelaksanaan UUD 1945, pelestarian Bhinneka Tunggal Ika serta pemertahanan dan pemeliharaan keutuhan NKRI; b) pembinaan persatuan dan kesatuan bangsa; c) pembinaan kerukunan antarsuku dan intrasuku, umat beragama, ras, dan golongan lainnya guna mewujudkan stabilitas kemanan lokal, regional, dan nasional; d) penanganan konflik sosial sesuai ketentuan peraturan perundang-undangan; e) koordinasi pelaksanaan tugas antar instansi pemerintahan yang ada di wilayah Daerah provinsi dan Daerah kabupaten/kota; f) pengembangan kehidupan demokrasi berdasarkan Pancasila; dan g) pelaksanaan semua Urusan Pemerintahan yang bukan merupakan kewenangan Daerah dan tidak dilaksanakan oleh Instansi Vertikal. 
Dari uraian di atas diketahui bahwa cara pemberian otonomi daerah di Indonesia yang dipakai dari masa ke masa adalah cara material dan cara residual. Dengan cara material, pusat menetapkan urusan/wewenang daerah yang rinci dan penyerahannya kepada daerah dilakukan secara bertahap. Sedangkan dengan cara residual, pusat menetapkan dulu urusan/wewenang yang ditanganinya, sisa selebihnya dijadikan otonomi daerah.

\section{Pasang-Surut Otonomi Daerah Di Indonesia}

Dari uraian diketahui bahwa di Indonesia sejak 1903 s.d sekarang telah terjadi pasang surut otonomi daerah yang disebabkan oleh adanya 'tarik-menarik kewenangan' antara Pusat dengan Daerah yang digambarkan dalam gerakan pendulum sentralisasi-desentralisasi berikut.

Gambar:

Pendulum Sentralisasi-Desentralisasi

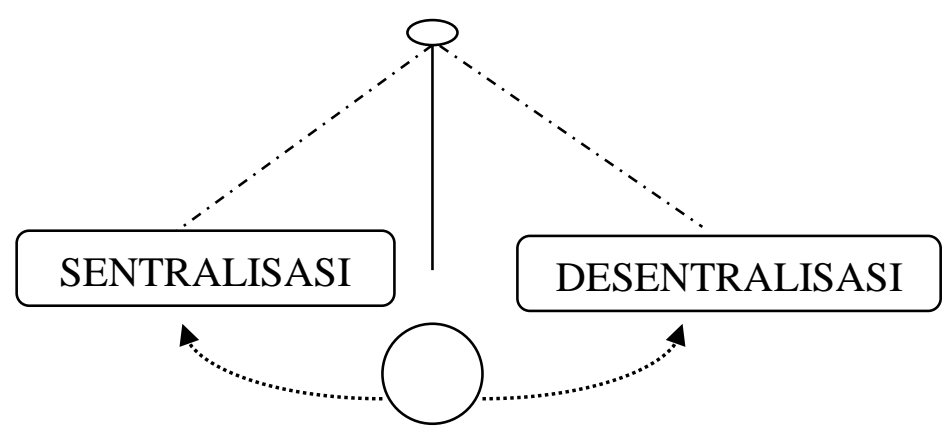

Pendulum (bandul) tarik menarik setralisasi-desentralisasi selalu bergerak menurut dinamika politik dari waktu ke waktu. Pada jaman penjajahan Belanda nuansa sentralisasi lebih kuat daripada desentralisasi. Otonomi daerah pada waktu itu diciptakan untuk meringankan beban penjajah dan bahkan untuk menjaga kelangsungan penjajahannya. Demikian pula yang terjadi pada jaman penjajahan Jepang. Kebijakan otonomi daerah dan implementasinya lebih diarahkan untuk menghadapi perang Asia Timur Raya.

Suasana itu berubah setelah Indonesia merdeka tahun 1945. Dalam suasana mempertahankan kemerdekaan pada masa pemberlakuan UU no.1 tahun 
1945, daerah-daerah diberikan keleluasaan untuk mengurus rumah-tangganya sendiri. Urusan yang diserahkan kepada daerah tidak dirinci. Pada saat ini pendulum berada di daerah desentralisasi yang nyaris ekstrim. Kemudian, dengan UU No. 22 Tahun 1948, mulai ada penetapan urusan yang diserahkan kepada daerah. Pendulum masih berada di area desentralisasi walaupun tidak seekstrem keadaan sebelumnya. Situasi politik terus berubah. Terjadi agresi Belanda dan pemberontakan dalam negeri sehingga dengan UU No. 1 tahun 1957 pemberian otonomi daerah didasari prinsip otonomi riil. Keadaannya mirip dengan suasana pada saat pemberlakuan UU No. 1 tahun 1945. Perkembangan selanjutnya, gangguan eksternal telah mereda namun keadaan politik di dalam negeri memanas sehingga dikeluarkan UU No. 18 tahun 1965 yang bernuansa desentralistik (prinsip otonomi riil) tetapi implementasinya tidak efektif. Pada masa pemberlakuan undang-undang ini, terjadi pergantian presiden dari Bung Karno kepada Pak Harto. Perhatian lebih ditujukan pada usaha stabilisasi polkam dalam negeri dan pembangunan sehingga dikeluarkan UU No. 5 tahun 1974. Walaupun prinsip pemberian otonomi riil diganti dengan prinsip otonomi yang luas, nyata, dan bertanggungjawab, namun dalam praktiknya tidak sepenuhnya demikian. Urusan daerah bertambah banyak tapi wewenangnya sedikit. Ibaratnya, kepala dilepas kaki diikat. Pada saat pemberlakuan undang-undang ini, pendulum bergerak lebih ke arah sentralisasi yang ditandai kuatnya aktivitas dekonsentrasi. Kemudian terjadi reformasi dan pada masa ini ditetapkan UU No.22 tahun 1999. Dengan undang-undang ini otonomi daerah kabupaten/kota membesar tapi provinsi mengecil sehingga kekuatan provinsi lemah. Pendulum lebih kuat berada pada area desentralisasi di kabupaten/kota. Kemudian dikeluarkan UU No. 32 tahun 2004 yang ditandai antara lain dengan menguatnya kembali otonomi daerah di provinsi. Akhirnya dengan UU No. 23 tahun 2014, pendulum berada dalam titik yang relatif seimbang antara kewenangan Pusat, Provinsi, dan Kabupaten/Kota. 


\section{KESIMPULAN}

Sebagai penutup dapat ditarik kesimpulan sebagai berikut:

1) otonomi daerah di Indonesia telah ada sejak tahun 1903 yang terbagi ke dalam 3 (tiga) masa yakni masa penjajahan Belanda, masa penjajahan Jepang, dan masa Indonesia merdeka;

2) dari sejak ada sampai sekarang, otonomi daerah di Indonesia mengalami pasang-surut mengikuti irama 'tarik-menarik kewenangan Pusat-Daerah' sesuai dengan perubahan situasi politik.

\section{DAFTAR PUSTAKA}

Anwar, Chairul, 2001, Konstitusi Dan Kelembagaan Negara,Jakarta:Novindo Pustaka Mandiri,.

Cheema, G. Shabbir; Rondinelli, Dennis A., 1983, Decentralization And Development, Policy Implementation In Developing Countries, United Nations Centre for Regional Development, California.

Gie, The Liang, 1967, Pertumbuhan Pemerintahan Daerah Di Republik Indonesia Jilid I,II, dan III, Jakarta : Gunung Agung.
------------------, 1977, Kumpulan Pembahasan Terhadap Undang-Undang Tentang Pokok-Pokok Pemerintahan Daerah Indonesia, Yogyakarta:Supersukses.

Jalal, Fasli, 1997, Peningkatan Kualias SDM Dalam Rangka Mewujudkan Otonomi Daerah, Makalah pada Semiloka Nasional Pemerintahan Yang Efektif dan Efisien Dalam Rangka Mewujudkan Otonomi Daerah, Jakarta.

Kansil, C.S.T ; Kansil, Cristine ST, 2001, Ilmu Negara (Umum Dan Indonesia), Jakarta:Pradnya Paramita.

Koswara, E, 2000, Makna Otonomi Daerah, Jurnal Ilmu Pemerintahan Edisi 10, Jakarta: Institut Ilmu Pemerintahan.

Ndraha, Taliziduhu, 2001, Ilmu Pemerintahan (Kybernology), Program Pascasarjana S2 dan S3 Kerjasama UNPAD-IIP.

Sugandha, Dann, 1981, Masalah Otonomi Serta Hubungan Antara Pemerintah Pusat Dan Daerah Di Indonesia, Bandung: Sinar Baru. 
Soejito, Irawan, 1976, Sejarah Pemerintahan Daerah Di Indonesia Jilid II, Jakarta, Yayasan Karya Dharma.

1981, Hubungan Pemerintah Pusat Dan Pemerintah Daerah, Jakarta, Bina Aksara.

Josef Riwu Kaho, 2002, Prospek Otonomi Daerah Di Negara Republik Indonesia, Jakarta:Raja Grafindo Persada.

H.A.W Widjaja, 2001, Titik Berat Otonomi Pada Daerah Tingkat II, Jakarta :Raja Grafindo Persada,.

Marsono, 2002, Susunan Dalam Satu Naskah UUD 1945 Dengan Perubahannya 1999-2002, Jakarta : Eka Jaya.

Wasistiono, Sadu, 1999, Sistem Pemerintahan Dan Otonomi Daerah, Bahan Kursus Reguler ke-23 Staf Umum dan Komando TNI-AD Tahun Akademik 1999/2000, Bandung: SESKOAD. 